Article

\title{
Management of Downstream Oil Palm Development in Technopolitan Area, Pelalawan Regency Indonesia
}

\author{
Zaili Rusli* ${ }^{*}$, Dadang Mashur ${ }^{2}$, Ringgo Eldapi Yozani ${ }^{3}$, Dedi Kusuma Habibie ${ }^{4}$, Khairul Amri ${ }^{5}$ \\ and Risky Arya Putri ${ }^{6}$, \\ 1 Department Of Public Administration, Universitas Riau 1; zaili.rusli@leceturer.unri.ac.id \\ 2 Department Of Public Administration, Universitas Riau 2; dadang.mashur@leceturer.unri.ac.id \\ 3 Department Of Communication Science, Universitas Riau 3; ringgo.eladpi@lecturer.unri.ac.id \\ 4 Department Of Public Administration , Universitas Riau 4; dedi.kusuma@lecturer.unri.ac.id \\ 5 Department Of Public Administration, Universitas Riau 5; kahirul.amri@lecturer.unri.ac.id \\ 6 Department Of Public Administration, Universitas Riau 3; resky.arya@lecturer.unri.ac.id \\ * Correspondence: zaili.rusli@leceturer.unri.ac.id \\ corresponding authors,Zaili Rusli (Z.L.)
}

\begin{abstract}
This study determines the management of downstream oil palm development in the technopolitan areas of Pelalawan Regency. The study object was analyzed qualitatively in stages, including the development, potential, and management of downstream oil palm. The results show that the downstream oil palm facilitates the development of various ideas, innovations, and knowledge from the use of products with high selling value. This supports the government, academia, business, and society in implementing Good Agricultural Practice (GAP). The downstream oil palm development in Pelalawan Regency is managed in an integrated, competitive, and sustainable manner. This allows all stakeholders and society (independent smallholders) to receive economic, social, and environmental benefits.
\end{abstract}

Keywords: Downstream oil palming; Management; Technopolitan

\section{Introduction}

Oil palm plantations are growing rapidly in most of Indonesia's provinces, occupying more than 11 million Ha. This huge plantation potential opens development opportunities in various sectors (Utomo, B.N., Widjaja, E., 2020). Various studies have been conducted on the development of sustainable oil palm plantations in Indonesia and related aspects. Specifically, most of these studies examined the extent of oil palm plantations development (Liu et al., 2020). Indonesia has 14 million hectares (ha) of oil palm and recorded exports of about USD 23 and 21 billion in 2017 and 2018, respectively (Purnomo, $\mathrm{H}$ et al., 2020).

Pelalawan Regency has a high potential for developing processed palm oil products, with 393,327 hectares of plantations. This includes 119,616 and 273,711 hectares of independent smallholders and private oil palm plantations, respectively (BPPT Pelalawan Regency, 2019). There are two types of oil palm plantations management. The first type is the plasma plantations, which involves cultivation and industrial plantation businesses by independent smallholders. The cultivation is conducted by individuals on freehold land or land use rights and plantation companies. Moreover, it is conducted on the land of Businesses use rights, ranging from seeding, planting, processing to marketing.

The second type of management is the plasma nucleus scheme, which is a partnership relationship between a group and a company. The partner company acts as the nucleus, while the group is the plasma. Oil palm development is the main economic activity in Pelalawan Regency. With an average economic growth rate of $4.52 \%$, it is significant for palm oil supply in Indonesia and the world. Oil palm management activities highly contribute to community income (Syahza, 2019). Due to the potential for economic improvement through oil palm management, the Pelalawan district government and BPPT 
developed a technopolitan area. This area brings together the government, academia, business, and the community for economic growth based on science, technology, and innovation.

The smallholder oil palm plantations covers around $31 \%$ of the total plantation area, with 40,315 independent farmer households. Most of these smallholders are not tied to large companies and have the potential to be developed to boost the regional economy. The development is based on the problems faced by independent smallholders in managing oil palm plantations without the basic Good Agricultural Practices (GAP), reducing farmer productivity (Ahmad, A.R., Nasir A.S.M, 2020). Furthermore, the Pelalawan district government is concerned with palm oil sales price margins. Studies have been conducted on the development of sustainable oil palm plantations in Indonesia, including Liu et al. (2020), Gonzalez et al. (2020), Widiati et al. (2020), Irawan et al. (2020). Also, Khairiza and Kusumasari (2020), Nurrochmat et al. (2020), Dharmawan et al. (2020), Martens et al. (2020), and Naylor et al. (2019) examined the policies and related aspects to determine the extent of the oil palm plantations development in Indonesia.

A technopolitan area has been set up as the downstream oil palm product development for economic improvement. The area is meant to be the Palm Oil Valley or integrated downstream oil palm development center. Several palm oil downstream products are used as the main sales icon, including Biofuels, Industrial Vegetables Oil (IVO) development, and tenant products, such as Praudi Express (palm oil stick machine), and JJE Cleaner (multipurpose cleaning fluid) (BPPT Pelalawan, 2019).

This study explains the management of regional downstream development. The study object is the downstream management of oil palm in the Pelalawan Regency. Sustainable industrial growth is enhanced by implementing key strategies, covering the entire process chain from upstream to downstream (Kushairi, A. et al., 2018). The management of downstream oil palm is based on its development and potential utilization in technopolitan areas. There is need for commitment and collaboration between the government, academics, business actors, and the community for an integrated, competitive, and sustainable development of downstream oil palm.

\section{Research Framework}

Regional development is conducted based on the principles and spirit of the community using its potential to improve people's welfare (Rusli, 2017). There is need for proper planning to direct the development of an area towards goal achievement (Murtiningrum, Oktoyoki 2019).

Regional development utilizes and combines existing internal (strengths and weaknesses) and external (opportunities and challenges) factors as potentials and opportunities to improve the production of goods and services. This is aimed to meet internal and external needs in the region, which include natural, human, and technological resources, and opportunities and threats, respectively. (Rusli, 2017).

Hagget, Cliff, and Frey in Rustiadi et al. (2018), regarding regional typology, classified the concept of a region into 3 categories, including uniform or homogenous, nodal, and planning or programming. Similarly, Glason in Putra (2018) classified regions into 3 categories based on the economic progress phase. The first phase includes the formal areas concerning uniformity or homogeneity. A formal area is geographically uniform based on certain criteria, such as economic, social, and political physical conditions. The second phase is the functional region concerning coherence and interdependence, which involves the mutual relations between the parts in the region. This phase is sometimes called a nodal or polarized region, consisting of heterogeneous units, such as rural-urban areas functionally related. The third phase is the planning area, which shows the coherence or unity of economic decisions. According to Zen in Walinaulik (2016), regional development is a harmonious relationship between natural resources, humans, and technology, based on the environment's capacity to empower society.

The Sustainable Development Goals (SDGs) applicable under the MDGs and integrated towards the post-2015 development agenda promote focused and coherent action. This should be in line with sustainable development discussed at the Rio + 20 conference held in 2012 (Rahdari, Sepasi, \& Moradi in Aparecida da Silva et al., 2018). SDG maintains a triple bottom line approach to maintaining human well-being in economic development, environmental sustainability, and social inclusion (Dhahri \& 
Omri, 2018). The concept of sustainable development was introduced in Agenda 21, which requires economic development to align with growth that meets human needs and protects the environment (United Nations, 2018).

Port infrastructure development is very costly, and its success or failure has long-term implications (Musso et. Al., In Putra 2016). Sustainable development is one of the complex long-term stages involving various disciplines (Yang et al., In Pratiwi 2018). Yan, Wang, Quan, Wu, and Zhao (2018) evaluated sustainable city development based on limited natural resources and human welfare needs. To assess oil palm sustainability, a model with the triple bottom line, consisting of the social and economic environment is needed (Kuok Ho Daniel Tang \& Hamad M. S. Al Qahtani, 2019).

A region is an area with a specific function, where its economic activities, sectors, and superior products have the potential to boost the economy of the surroundings (Murtiningrum, Oktoyoki 2019). Furthermore, Tarigan (2016) stated that the area forms clusters, such as agriculture. Planning is setting a goal and selecting the steps needed for its achievement. Therefore, implementing sustainable development is a wise choice suggested in area management (Rusli, 2017). This study qualitatively describes the management of downstream oil palm development based on regional, sustainable, and technopolitan area development in the Pelalawan Regency.

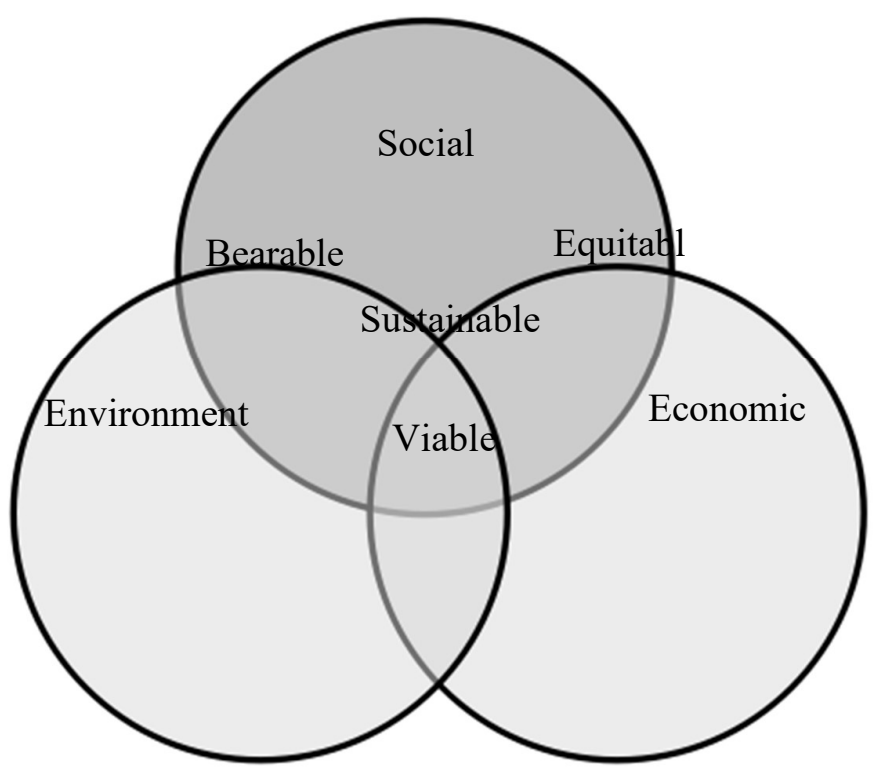

Figure 1. Three Pillars of the Sustainable Development Approach 
4 of 16

\section{Materials and Methods}

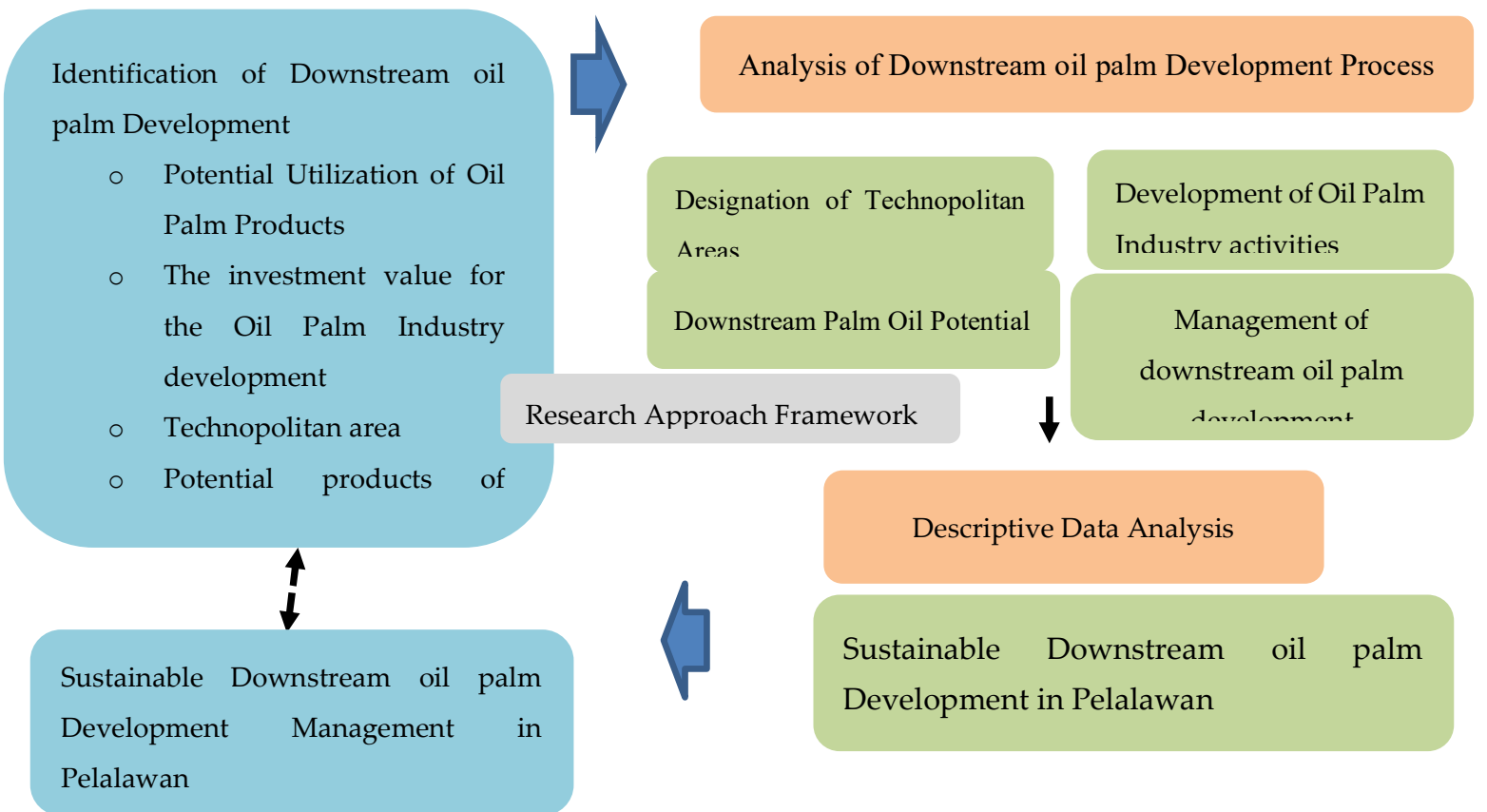

This research focuses on the management of downstream oil palm development in the technopolitan area of Pelalawan district. Qualitative analysis was conducted on the object of study in stages, including the development, analyzing the potential, and the governance of downstream oil palm in technopolitan areas.

The information in this study was obtained from technopolitan area planning documents and other supporting sources. Data were collected through interviews and Focus Group Discussions (FGD). The implementing actors included the government, academics, business people, and the community. Data analysis involved 3 activities, including reduction, presentation, and conclusion drawing (Miles and Huberman, 2014).

\section{Results}

\section{Downstream Oil Palm Development in Technopolitan Areas}

Techno Park / Teknopolitan is an area with various activities for the development of technology and knowledge, empowerment and training. Moreover, there is an education in one area equipped with various facilities and infrastructure supporting economic growth, innovation, and technology. A technopolitan is developed to create sustainable synergy between universities (academics), industry players, government, and society. Also, technopolitan areas are used as centers for the growth and development of industrial products and their diversification, improving industrial competitiveness.

Nationally, Indonesia still lacks a successful example of a technopolitan area, though efforts are made for development. This is in line with the government's efforts to use appropriate technology that meets the needs of society efficiently and effectively, and does not damage the environment. Moreover, this technology should increase added value to help accelerate the economy and environment. In the context of downstream oil palm, development is based on updating appropriate technology for the plantation 
sector. Productive activities, as well as community movements that support the acceleration of innovation and learning, are elements of success in development. This is because the application of good technology must be supported by participation and good human resources.

A technopolitan is a special area built based on a commitment to have one or more centers of science and technology activities. These areas link higher education, research, and development institutions, as well as the industry as a vehicle for strengthening networks within an innovation system (Warseno, 2014). Increasing added value downstream requires a variety of scientific and technological approaches in line with the goals of the technopolitan area and depends on healthy industrial growth. The improved conditions of Domestic Investment (PMDN) and Foreign Investment (PMA) in Pelalawan Regency indicates attractiveness and improved competitiveness.

Figure 3 shows the investment value of PMDN and PMA in Pelalawan Regency from 2016 to 2019

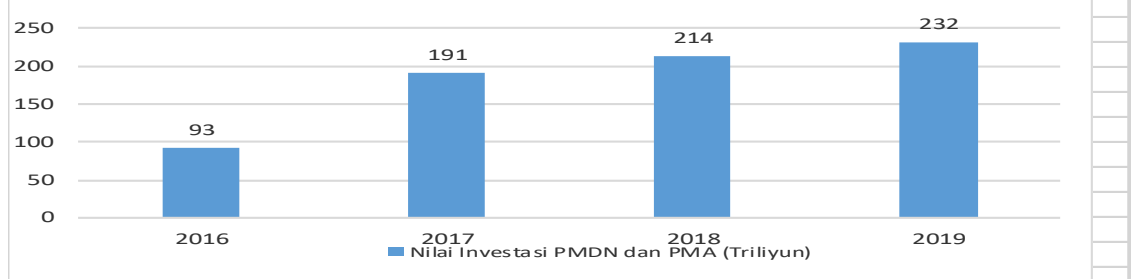

Figure 3: Graph of the PMíìN and P̉MÁA ìnvestment Value in Pelalawan Regency

Source: One Door Integrated Service and Service Investment Office, Pelalawan regency 2020.

The Pelalawan Regency Government and the Agency for the Assessment and Application of Technology (BPPT) have developed a technopolitan area since 2012. It serves as a vehicle for education, developing innovation, and palm-based technology. Pelalawan Technopolitan area is the largest in Indonesia. With an area of 3,754 hectares, it is one of 5 technopolitans that have become pilot projects.

The need for downstream oil palm development is based on several factors. First, the growth in the production of coconut, rubber, and oil palm plantations is still dominated by oil palm production. For instance, 1,886,470 tons of oil palm were produced in 2019, while the production of rubber and coconut in the same year was 34,780 tons and 15,283 tons, respectively (Central Statistics Agency of Pelalawan Regency: 2019). Palm oil is one of the best raw materials for food processing companies due to its versatility, availability, low cost, and guaranteed supply (Guadalupe et al., 2019). The determination of the Technopolitan area in Pelalawan Regency is the right step towards developing the regional potential to improve the community's economy and empower independent farmers.

Second, the entry of the Technopolitan Area into the Sumatra Economic Corridor impacts the development of trade connections between regions in the Sumatra island. Furthermore, it supports the efficient and effective distribution of oil palm plantation products. The provision of these facilities stimulates economic movement in the oil palm plantation sector, including the downstream, which requires high connectivity to marketing logistics.

The third factor is the development of oil palm as the main economic activity in the Pelalawan Regency. The natural resources production (oil palm plantations) in Pelalawan Regency is high. This is evidenced by the percentage of oil palm production in Riau Province in 2013-2014, which is high by 7.84\%, compared to Regencies and Cities, which tend to decline (Data from Disbun Riau Province 2015). The high production potential could be utilized for other products using large raw materials, such as biofuel made from palm oil. 
6 of 16

Fourth, opportunities for the community to be actively involved in any oil palm plantation business activities are more open. Most oil palm farmers are currently focused on increasing the yield of fresh fruit bunches (FFB). However, a technopolitan area improves the transfer of knowledge on cultivation, management, and utilization of oil palm plantation products, empowering the community towards GAP (Good Agriculture Practice). Consequently, community-based empowerment improves the effective and efficient organizing of independent smallholders in the Pelalawan Regency, especially in oil palm plantation actors (Amri, 2020).

The Pelalawan Techno Park area is divided into 7 zones, including education, research, industry, residential, conservation, commercial and public. A Pelalawan Technopolitan High School (ST2P) has been built in an education zone covering 100 hectares. Figure 4 shows the zoning of technopolitan areas.

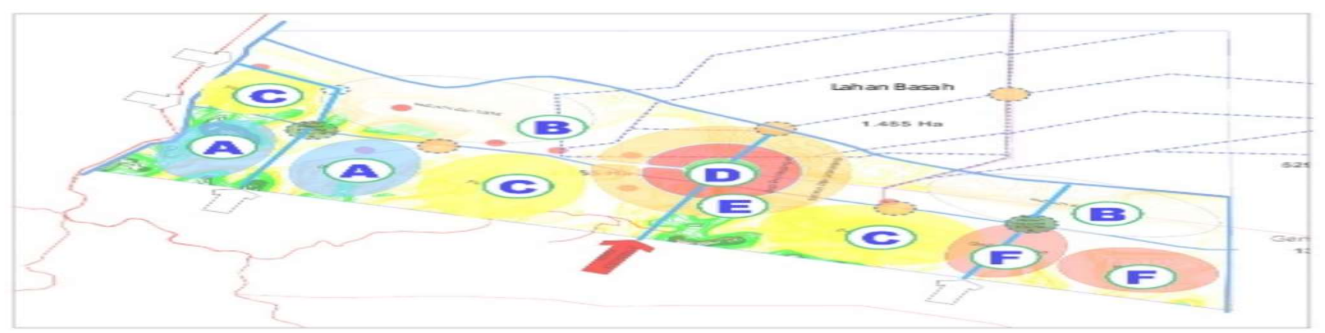

Figure 4: Block Distribution Map for the Technopolitan Pelalawan Area

The downstream oil palm in a technopolitan area facilitates the development of various ideas, innovations, and know-how from the academic, as well as the financial and marketing capabilities of the business world. This combination increases and accelerates product development. Furthermore, it reduces the time required to move innovation to marketable products to obtain a high economic return (BPPT Pelalawan, 2015).

\section{Discussion}

\section{Potential Downstream of Oil Palm in Technopolitan Areas}

The discourse of downstream oil palm in Indonesia emerged in 2010. Downstream is a structural change effort to transform traditional exportation of palm oil products into modern selling of their derivatives overseas. The government plays two roles in facilitating structural change through downstream, specifically acting as an entrepreneur and manager of conflicts.

Downstream industry development is aimed at maintaining a strategic position from the upstream to the downstream industry. The downstream oil palm is accelerated by increased productivity of plantations and the development of technopolitan areas. Moreover, innovations in palm oil derivative products in the community are stimulated by the availability of various facilities, including educational and infrastructure, in the development of plantations in technopolitan areas. Indonesian oil palm plantations are growing rapidly in various regions. Statistics show that 22 provinces have developed the oil palm plantation sector, with 5 becoming business centers. Based on its distribution, the Sumatra island has become productive in plantation development, especially in Riau, North, and South Sumatra provinces. Oil palm mills (PKS) are spread along the plantations. From the 608 PKS units and with a productivity of 34,280 tons of FFB per hour, most of them are located in 5 palm oil center provinces. They account for $64 \%$ of Indonesia's oil palm plantation area, producing around $70 \%$ of national CPO. 
7 of 16

The data from the Department of Horticultural and Plantation Food Crops of Riau Province and Indonesian Palm Oil Statistics in 2017 shows that there are 32 PKS in Pelalawan Regency, with a productivity of 1,875 tons per hour. Furthermore, the oil palm plantations area reached 393,327 hectares. The private plantations total 273,711 hectares, while people's settlement totals to 119,616 hectares. The oil palm plantations in the Pelalawan Regency cover $16.04 \%$ of the total area in Riau Province.

Though there is increased investment and the area of oil palm plantations in the Pelalawan Regency, the local government and other parties take advantage of the existing potential to exploit farmers. The ability of the agricultural and oil palm plantation sectors creates a working environment for young people (Kamaruddin, 2018). The cooperation of various parties in the development of palm oil downstream innovation by the Innovation Center in a technopolitan area produces products utilized by the community. Downstream oil palm development includes oleo food (oleo food complex), oleochemical, and biofuel complexes. First, the downstream Oleo food (oleo food complex) develops products produced between oleo food (intermediate oleo food) to oleo food products, such as palm cooking oil and margarine.

Second, downstream oleochemicals (oleochemical complex) are produced by basic oleochemicals to finished products, such as detergents, shampoo, and soap, among others. Third, Biofuel Downstream (Biofuel Complex) is produced between biofuels and finished products, such as biodiesel and bioavtur. Figures 5 shows a labor-intensive development in the 3 downstream oil palm plantations in a technopolitan area.

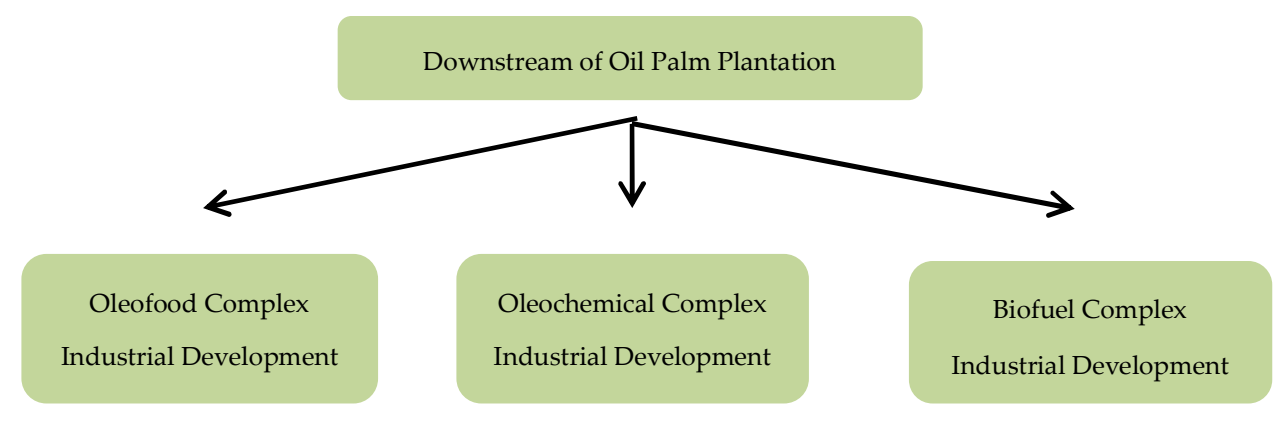

Figure 5: Downstream oil palm Labor-Intensive Development

The biodiesel biofuel industry is currently one of the main targets for development. This is based on various considerations, including the use of new and renewable energy (EBT) in Indonesia and increase added value from raw to finished materials.

\section{Management of Downstream Oil Palm Development in Technopolitan Areas}

In terms of economic development, oil palm plantations have continued to increase. Oil palm is the most productive oil crop, with yields per hectare about 9 times than soybeans (Basiron, de Vries et all in Verneau et al., 2019). The Directorate General of Plantation of the Ministry of Agriculture noted that in the next 5 years (2020-2024), the government is targeting to invest a total of IDR 2,231.5 trillion in the agricultural sector, or an increase of $827 \%$. Additionally, the agricultural sector workforce is targeted to increase by 3.26 million people (8.4\%) (Dirjenbun, 2019)

According to business status on most oil palm plantations in 2018, the land cultivated by large private plantations was 6.36 million hectares (49.81\%). Also, 5.81 (45.54\%) and 0.59 million hectares were cultivated by smallholders and large state plantations, respectively (Statistic Indonesia 2019). 


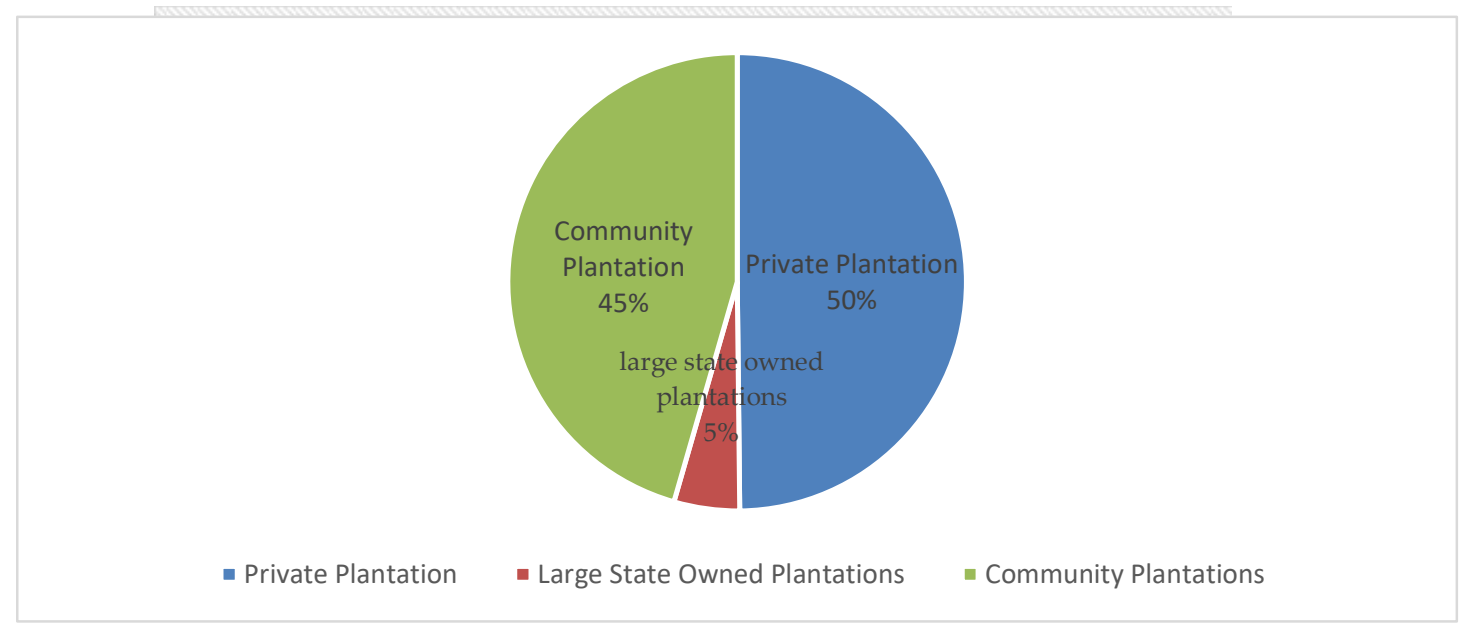

Figure 6: Comparison of Oil Palm Plantation Areas by Business Status

The ownership status data show that the size of oil palm plantation owned by independent smallholders is $45.54 \%$. This large area allows the management of downstream oil palm development to focus more on smallholders. Therefore, efforts to increase the empowerment of independent smallholders to be involved in the downstream of oil palm are realized properly.

The achievement of the Indonesian oil palm industry development is inseparable from the contribution of independent smallholder plantations. In 2017, it reached $40.01 \%$ of the total national oil palm area. This accounted for $22.64 \%$ of the total national production. In line with this, the government has made various efforts to strengthen the role of independent smallholders in sustainable oil palm cultivation, including in the development of the downstream industry. Smallholder oil palm plantations in Riau are rapidly growing. However, this growth is not accompanied by the development of the processing industry, resulting in an accumulation of raw materials (Syahza and Asmit, 2019).

The development of the downstream industry (agro-industry) is very strategic when carried out in an integrated and sustainable manner. Integrated means there are linkages between upstream and downstream sector businesses in a synergic and productive manner. Also, there are linkages between regions, sectors, and even commodities. Sustainability is meeting the present needs without reducing the ability of the next generation to meet their needs (World Commission on Sustainability). CPO downstream efforts need to be addressed positively. This is due to the many derivative products with the potential to be developed from the above CPO commodities, as well as the added economic value that could be generated. The management of downstream oil palm development in the Pelalawan Regency is implemented in an integrated, competitive, and sustainable approach. This enhances each planning, implementation, and evaluation process that simultaneously develops an area in 7 zones. The technopolitan area is developed by applying various aspects of knowledge, technology, environment, economy, and socio-culture. Therefore, the area is hoped to contribute effectively and efficiently to the empowerment of a competitive and sustainable community. The following descriptions are related to the management of palm oil downstream development in the Pelalawan Regency.

First, integrated development in Pelalawan Regency's technopolitan area shows that the government and various other parties cooperate according to their areas of expertise and authority. Those involved in developing a technopolitan area include the Regional Government of Pelalawan 
9 of 16

Regency, the Research Agency and Application of Technology, Indonesian Palm Oil Council, PT. Pindad (Persero), PT. Engineering, Oil Palm Research Center, and Bandung Institute of Technology (ITB).

The second factor is competitiveness. The potential for oil palm plantation growth and utilization of the products in Indonesia is inadequate when compared to Malaysia (Hashemvand and Takeuchi, 2020). This partly explains the utilization and maximization of the potential of oil palm plantations. The Oil Palm Research Center and technological support from the Bandung Institute of Technology (ITB) colleges prepare and empower independent smallholders to enter the certified market. Additionally, the smallholders are empowered to have their factories with the development of Industrial Vegetable Oil (IVO) production made from Industrial Palm Oil (IPO). This is meant to supply raw materials for the Pertamina Oil Refinery Co-Processing in Dumai to produce biofuel. Furthermore, related parties help fulfill the ISPO certification for both companies and independent smallholders for a sustainable downstreaming. This is to Ensure the increased competitiveness of palm oil in the world market. The principles and criteria applied are the Indonesian government's efforts to realize sustainable oil palm plantation development (Habibie, 2018).

A biorefinery development refers to exploring biomass to be produced into fuel, energy, and chemicals used in life. Biorefinery is developed to increase its role in fulfilling global sustainability efforts (Harahap et al., 2020).

Third, sustainability. Public awareness at the local and national levels has increased. Various aspects of economic, socio-cultural, and environmental policies are considered in the planning, implementation, and management of the area. The various actors involved are prepared to fulfill the management of oil palm plantations under the SDGs direction, as well as the principles of ISPO and RSPO. Furthermore, the application of GAP (Good Agriculture Practice) becomes a guideline for both companies and independent smallholders to sustainably optimize the management of oil palm plantations, as well as an effort to counter the negative issues of plantations. The public's negative view of palm oil is due to greed, corruption, profit, and capitalism (Teng et al., 2020).

Implementing GAP, accompanied by supportive government policies, improves the success of sustainable oil palm plantation management. The management needs to pay attention to policy acceptance, adoption, and strategic readiness (Rusli, 2018).

The governance of downstream oil palm development in technopolitan areas is generally described as follows: 


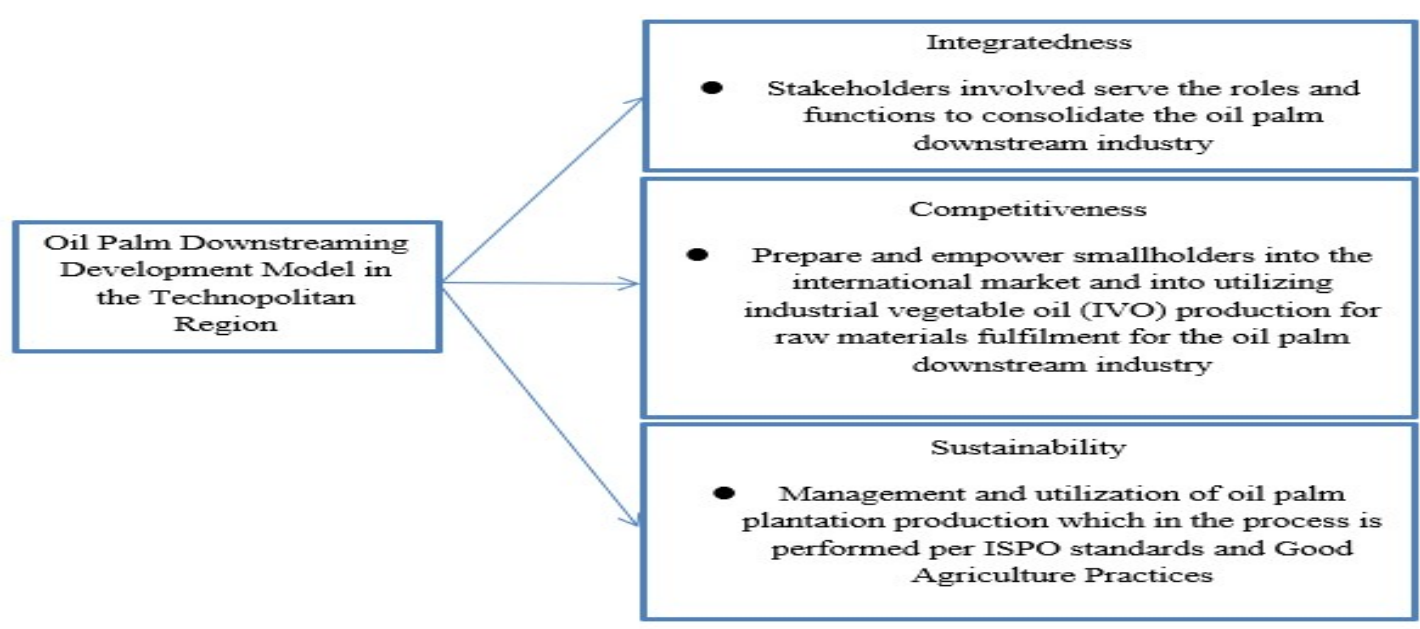

Figure 7: Management of Downstream oil palm Development in Technopolitan Areas

In its application, the management realizes the development of a sustainable downstream oil palm industry. This is supported by the large opportunities for independent farmers to be involved in various production and cultivation activities that pay attention to environmental and legality aspects. An important point obtained from a technopolitan area is community empowerment in oil palm management based on technology, environment, and legality.

The following is a cooperation scheme for the development of Pelalawan technopolitan to empower and prosper the oil palm farmers.

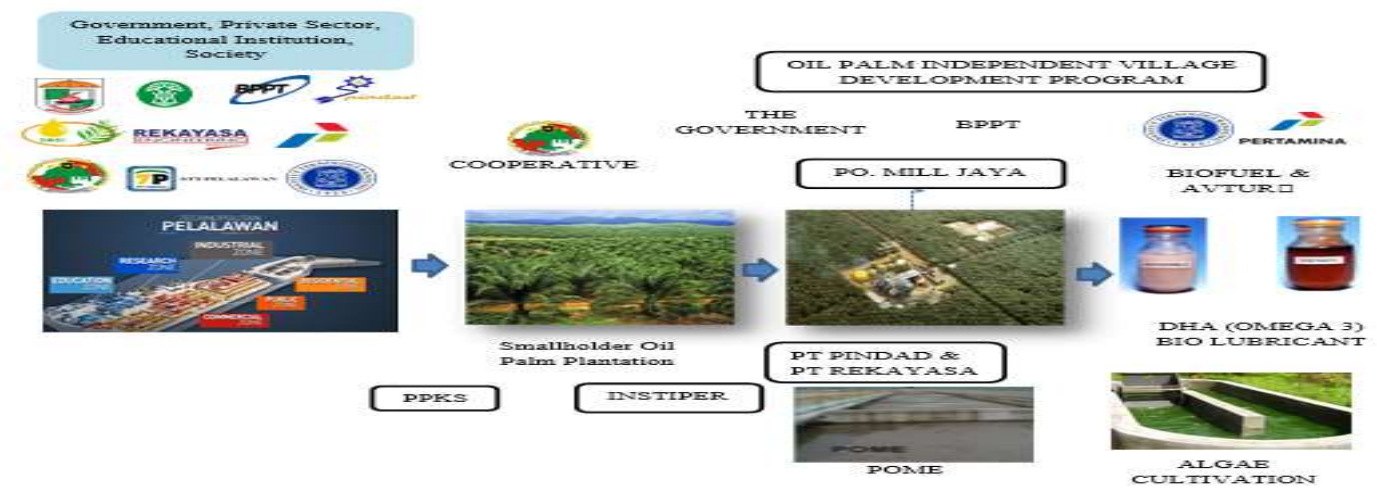

Support from the various parties involved and the active role of the community is a form of good development among the government, business, society, and academia. It facilitates the realization of Good Agriculture Practice and the fulfillment of various ISPO principles in ensuring sustainable oil palm management. To ensure the active participation of independent smallholders, it is necessary to establish an institution that facilitates the communities at the local level. An institution should have a specific function of meeting various human needs. This institution has a broad definition, including the notion of farmer organizations, as well as the role of the game or rules of behavior that determine patterns of action and social relations. An example is a social unity, which is a concrete form of that institution. Also, collaborative arrangements support sustainable agricultural production systems (Futemma, 2020). 
Independent smallholder institutions, such as cooperatives, are essential in influencing the implementation of downstream oil palm. First, the oil palm land in Pelalawan Regency, owned by independent smallholders, is quite large, covering 119,616 ha. The number of independent smallholder households is 40,315. Second, this cooperative institution could realize sustainable management of independent smallholders' plantations by partnering with the Pelalawan Institute of Technology Innovation Center (PI-ST2P) in the technopolitan area. The PI-ST2P could provide advocacy and innovation in the development of downstream oil palm.

Third, cooperative institutions contribute to increasing the number of ISPO certifications. The activities of the Oil Palm Independent Village Program from several cooperatives and the Amanah UKUI Association (the First Independent Farmers Group in Indonesia with ISPO certification) influence other independent smallholder groups. As a result, the independent smallholder groups implement oil palm plantation management under ISPO principles.

The following approaches are found based on various development models. First, The early development of International New Ventures: a multidimensional exploration. This paper stated that initial development for new businesses in the international world takes advantage of strategic, managerial, financial, and social capital to recognize and grasp new opportunities (Kirwan, 2019). In line with this, the business potential or investment in oil palm plantations is classified as high. Therefore, based on this research opinion, the use of oil palm plantation investment supports new businesses in the downstream sector.

Second, Library and information science and sustainable development: a structured literature review. This paper found that from the various existing literature or articles, sustainable development is currently focused on understanding approaches. Furthermore, related to sustainability, it still focuses on information and communication technology or information systems. Only a few articles discuss further topics, such as government, city development, or scientific results (Meschede, 2019). The current sustainable development model still focuses on finding a suitable approach. Furthermore, sustainable development is interpreted as creating information systems in the management of a technopolitan area. It utilizes various meanings of sustainable development, such as the use of technology and knowledge. Education is supported in physical development, such as constructing buildings, roads, and infrastructure for technopolitan areas.

Third, System dynamics models for the simulation of sustainable urban development: A review, analysis, and the stakeholder perspective. This article reviews regional development models. In this article, a sustainable development model must focus on environmental issues, social capital, as well as life-supporting advice and infrastructure, including water resources (land, water) and waste management (Pejic Bach, 2019). Development management implemented in technopolitan areas applies the principle of sustainability. Furthermore, it pays attention to environmental aspects in various matters, such as environmental education, as well as the development of the area and downstream industry. The interesting thing in the management of a technopolitan area development is the presence of government, society, academics, and businesses that focus on environmental-based economic empowerment.

The technopolitan area development is managed through education, knowledge, technology, environment, economy, and socio-culture in applying the downstream oil palm industry in the 
Pelalawan Regency. An integrated, competitive, and sustainable approach serves as a guideline in every planning, implementation, and development of a technopolitan area. This aims to achieve the goals and benefits of technopolitan, including community empowerment through the downstream oil palm industry.

\section{Conclusions}

The management of downstream oil palm development in Pelalawan Regency is implemented in an integrated, competitive, and sustainable approach. The downstream oil palm in technopolitan areas facilitates the development of various ideas, innovations, and know-how from the academic, financial, and marketing capabilities in business. This is part of solving oil palm plantation management problems, which only focuses on economics. The development is expected to solve various challenges in developing the downstream industry that empowers independent farmers. Essentially, the development of the downstream industry is very strategic and competitive when conducted in an integrated and sustainable manner. Integrated means there are linkages between upstream and downstream sector businesses in a synergic and productive manner, as well as between regions, sectors, and commodities. Support from various parties involved and the active community role is a form of good development between government, business, society, and academia. The support is meant to realize Good Agriculture Practice and fulfill various ISPO principles in sustainable palm oil management.

Author Contributions: Conceptualization, Zaili Rusli. and Dadang Mashur.; methodology, Zaili Rusli.; software, Dedi Kusuma Habibie.; validation, Ringgo Eldapi Yozani., Risky Arya Putri. and Zaili Rusli.; formal analysis, Zaili Rusli.; investigation, Khairul Amri.; resources, Zaili Rusli.; data curation, Dedi Kusuma .; writing-original draft preparation, Dedi Kusuma.; writing - review and editing, Risky Arya Putri.; visualization, Dedi Kusuma Habibie supervision, Zaili Rusli.; project administration, Kahirul Amri.; funding acquisition, Zaili Rusli. All authors have read and agreed to the published version of the manuscript.

Acknowledgments: To the Institute for Research and Service, Universitas Riau and the Government of Pelalawan Regency, especially the Technopolitan Unit of Pelalawan Regency

Conflicts of Interest: The results of this study are not related and will lead to personal or institutional conflict because it has been done scientifically. 


\section{References}

1. Ahmad, A.R., Nasir, A.S.M. 2020. The practices and factors affecting the implementation of integrated cattle and oil palm farming systems in Malaysia. Humanities and Social Sciences Reviews 8(4), pp. 693-700

2. Aparecida da Silva et.all. (, 2018). Urban resilience and sustainable development policies An analysis of smart cities in the state of São Paulo. Revista de Gestão Vol. 27 No. 1, 2020 pp. 61-78 Emerald Publishing Limited eISSN: 2177-8736 p-ISSN: 1809-2276. DOI 10.1108/REGE-12-2018-0117.

3. BPPT Kabupaten Pelalawan. (2019). Perencanaan dan Pengembangan Kluster Industri Hilir Sawit. Kabupaten Pelalawan.

4. Badan Pusat Statistik Kabupaten Pelalawan (2019). Produksi Perkebunan Menurut Kecamatan dan Jenis Tanaman di Kabupaten Pelalawan, 2016-2019. Available from: https://pelalawankab.bps.go.id/dynamictable/2019/11/21/90/produksi-perkebunan-menurut-kecamatan-danjenis-tanaman-di-kabupaten-pelalawan-2016-2019.html

5. Badan Pusat Statistik Kabupaten (2019). Statistik Kelapa Sawit Indonesia 2018: Indonesian Oil Palm Statistics 2018.

6. Dhahri, S., \& Omri, A. (2018). Entrepreneurship contribution to the three pillars of sustainable development: What does the evidence say?. World Development, 106(2018), 64-77.

7. Dharmawan, A. H., Fauzi, A., Putri, E. I. K., Pacheco, P., Dermawan, A., Nuva, N., ... Sudaryanti, D. A. (2020). Bioenergy policy: The biodiesel sustainability dilemma in Indonesia. International Journal of Sustainable Development and Planning, 15(4), 537-546. DOI:10.18280/ijsdp.150414

8. Futemma, C., De Castro, F., \& Brondizio, E. S. (2020). Farmers and social innovations in rural development: Collaborative arrangements in eastern Brazilian Amazon. Land use Policy, 99 DOI:10.1016/j.landusepol.2020.104999

9. Guadalupe, G.A., Lerma-García, M.J. Fuentes, A., Barat, J.M., Bas, M.d.C. and Fernández-Segovia, I. (2019), "Presence of palm oil in foodstuffs: consumers' perception", British Food Journal, Vol. 121 No. 9, pp. 21482162. https://doi.org.ezproxy.ugm.ac.id/10.1108/BFJ-09-2018-0608

10. Gonzalez-Redin, J., Polhill, J. G., Dawson, T. P., Hill, R., \& Gordon, I. J. (2020). Exploring sustainable scenarios in debt-based social-ecological systems: The case for palm oil production in Indonesia. Ambio, 49(9), 15301548. DOI:10.1007/s13280-019-01286-8

11. Hashemvand Khiabani, P., \& Takeuchi, W. (2020). Assessment of oil palm yield and biophysical suitability in Indonesia and Malaysia. International Journal of Remote Sensing, 41(22), 8520-8546. DOI:10.1080/01431161.2020.1782503

12. Harahap, F., Leduc, S., Mesfun, S., Khatiwada, D., Kraxner, F., \& Silveira, S. (2020). Meeting the bioenergy targets from palm oil-based biorefineries: An optimal configuration in Indonesia. Applied Energy, 278 DOI:10.1016/j.apenergy.2020.115749

13. Habibie, Dedi. Kusuma. (, 2018). Political Economy Of Indonesia Sustainable Palm Oil (ISPO) Certification System in Riau Province. Annual Conference of Asian Association for Public Administration: "Reinventing Public Administration in a Globalized World: A Non-Western Perspective" (AAPA 2018), 191,19-28. https://doi.org/10.2991/aapa-18.2018.3

14. Irawan, S., Widiastomo, T., Tacconi, L., Watts, J. D., \& Steni, B. (2019). Exploring the design of jurisdictional REDD+: The case of Central Kalimantan, Indonesia. Forest Policy and Economics, 108 DOI:10.1016/j.forpol.2018.12.009 
15. Kamaruddin, R. Abdullah, N. and Ayob, M.A. (2018), "Determinants of job satisfaction among Malaysian youth working in the oil palm plantation sector,"

Journal of Agribusiness in Developing and Emerging Economies, Vol. 8 No. 4, pp. 678692. https://doi.org.ezproxy.ugm.ac.id/10.1108/JADEE-06-2017-0063

16. Khairiza, F., \& Kusumasari, B. (2020). Analyzing political marketing in Indonesia: A palm oil digital campaign case study. Forest and Society, 4(2), 294-309. DOI:10.24259/fs.v4i2.9576

17. Khairul Amri, \& Adia Ferizko. (2020). Manajemen Pemberdayaan Masyarakat Desa Di Kabupaten Bengkalis. Jurnal Niara, 13(1), 227-236. https://doi.org/10.31849/niara.v13i1.4106

18. Kuok Ho Daniel Tang \& Hamad M. S. Al Qahtani. 2019. Sustainability of oil palm plantations in Malaysia. Environment, Development, and Sustainability volume 22, pages4999-5023(2020)

19. Kashmiri, A. et al., 2018. Oil palm economic performance in Malaysia and r\&d progress in 2017. Journal of Oil Palm Research Volume 30, Issue 2, June 1, 2018, Pages 163-195

20. Kirwan, P. Ratinho, T. van der Sijde, P. and Groen, A.J. (2019), "The early development of International New Ventures: a multidimensional exploration," International Journal of Entrepreneurial Behavior \& Research, Vol. 25 No. 6, pp. 1340-1367. https://doi.org.ezproxy.ugm.ac.id/10.1108/IJEBR-12-2017-0508

21. Kementerian Pertanian Republik Indonesia (2019). Kementan Dorong Investasi Perkebunan ke Industri Hilir untuk Ekspor. Available from: https://www.pertanian.go.id/home/?show=news\&act=view\&id=3974

22. Liu, F. H. M., Ganesan, V., \& Smith, T. E. L. (2020). Contrasting sustainability science communications in palm oil agriculture's media coverage on tropical peatlands in Indonesia, Malaysia, and Singapore. Environmental Science and Policy, 114, 162-169. DOI:10.1016/j.envsci.2020.07.004

23. Martens, K., Kunz, Y., Rosyani, I., \& Faust, H. (2020). Environmental governance meets reality: A micro-scale perspective on sustainability certification schemes for oil palm smallholders in Jambi, Sumatra. Society and Natural Resources, 33(5), 634-650. DOI:10.1080/08941920.2019.1674436

24. Miles, M. B., Huberman, M. A., \& Saldaña, J. (2014). Qualitative Data Analysis. A Methods Sourcebook. Zeitschrift Für Personalforschung, 28(4), 485-487. https://doi.org/10.1136/ebnurs.2011.100352

25. Murtiningrum, Fery, and Hefri Oktoyoki (2019), “ Perencanaan Pengembangan Kawasan Kopi di Kabupetan Rejang Lebong, Provinsi Jambi “. Agro Bali, Vol. 2 No. 2, Desember 2019: 121-129, doi https://doi.org/10.37637/ab.v2i2.383

26. Meschede, C. and Henkel, M. (2019), "Library and information science and sustainable development: a structured literature review," Journal of Documentation, Vol. 75 No. 6, pp. 13561369. https://doi.org.ezproxy.ugm.ac.id/10.1108/ID-02-2019-0021

27. Naylor, R. L., Higgins, M. M., Edwards, R. B., \& Falcon, W. P. (2019). Decentralization and the environment: Assessing smallholder oil palm development in Indonesia. Ambio, 48(10), 1195-1208. DOI:10.1007/s13280-0181135-7

28. Nurrochmat, D. R., Boer, R., Ardiansyah, M., Immanuel, G., \& Purwawangsa, H. (2020). Policy forum: Reconciling palm oil targets and reduced deforestation: Landswap and agrarian reform in Indonesia. Forest Policy and Economics, 119 DOI:10.1016/j.forpol.2020.102291

29. Rahmayanti, F. D., Diana, T. B., \& Husni, H. (2020). Efektivitas Lubang Resapan Organopori Dalam Menahan Laju Erosi Dan Stabilitas Ekologi Tanah Pada Aliran Das Citarum, Dusun Tujuh, Desa Mulyasejati, Kabupaten Karawang, Jawa Barat. Abdi Wiralodra : Jurnal Pengabdian Kepada Masyarakat, 2(1), 1-15. https://doi.org/10.31943/abdi.v2i1.19 
30. Rahdari, A., Sepasi, S., \& Moradi, M. (2016). Achieving sustainability through Schumpeterian social entrepreneurship: The role of social enterprises. Journal of Cleaner Production, 137(2016), 347-360.

31. Rusli, Zaili. (2017). Tata Kelola Pembangunan Kawasan. Pekanbaru: Alaf Riau

32. Rusli, Z. (2018), "The implementation of palm oil plantation business licensing", International Journal of Law and Management, Vol. 60 No. 3, pp. 770-776. https://doi.org.ezproxy.ugm.ac.id/10.1108/IJLMA-03-2017-0030

33. Rustiadi, Ernan. (2018). Perencanaan dan pengembangan wilayah. Yayasan Pustaka Obor Indonesia.

34. Tarigan, R. (2016). Perencanaan Pembangunan Wilayah. Jakarta: PT. Bumi Aksara

35. Utomo, B.N., Widjaja, E. 2020. The integration of oil palm and cattle (ISAPI) by a group of farmers and its development strategy in Lamandau District, Central Kalimantan Province. IOP Conference Series: Earth and Environmental ScienceVolume 492, Issue 1, June 23, 2020, Article number 01206

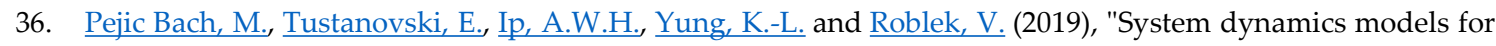
the simulation of sustainable urban development: A review and analysis and the stakeholder perspective," Kybernetes, Vol. 49 No. 2, pp. 460-504. https://doi.org.ezproxy.ugm.ac.id/10.1108/K-04-2018-0210

37. Purnomo et al., 2020. Reconciling oil palm economic development and environmental conservation in Indonesia: A value chain dynamic approach. Forest Policy and Economics Volume 111, February 2020, Article number 102089

38. Putra, Hendra. Tingkat Partisipasi Masyarakat Transmigran dan Masyarakat Lokal dalam Pengembangan Wilayah Pedesaan di Kabupaten Luwu Timur (studi kasus: desa bawalipu kecamatan wotu). Diss. Universitas Islam Negeri Alauddin Makassar, 2018.

39. Putra, Adris A., and Susanti Djalante. "Pengembangan Infrastruktur Pelabuhan Dalam Mendukung Pembangunan Berkelanjutan."Jurnal Ilmiah Media Engineering Vol.6 No.1, Januari20116(433-4) ISSN:20879334

40. Pratiwi, Niken, Dwi Budi Santosa, and Khusnul Ashar. (2018). "Analisis Implementasi Pembangunan Berkelanjutan di Jawa Timur." Jurnal Ilmu Ekonomi Dan Pembangunan Vol 18, No. 1 (2018): 1-13. JIEP-Vol. 18, No 1, Maret 2018ISSN (P) 1412-2200 E-ISSN 2548-1851.

41. Syahza, A. and Asmit, B. (2019), "Development of palm oil sector and future challenge in Riau Province, Indonesia," Journal of Science and Technology Policy Management, Vol. 11 No. 2, pp. 149170. https://doi.org.ezproxy.ugm.ac.id/10.1108/JSTPM-07-2018-0073

42. Teng, S., Khong, K. W., \& Che Ha, N. (2020). Palm oil and its environmental impacts: A big data analytics study. Journal of Cleaner Production, 274 DOI:10.1016/j.jclepro.2020.122901

43. United Nations (2018). Sustainable Development Goals. Available from: https://sustainabledevelopment. un.org/sdgs (accessed July 6, 2020).

44. Verneau, F., La Barbera, F., Amato, M. and Sodano, V. (2019), "Consumers' concern towards palm oil consumption: An empirical study on attitudes and intention in Italy," British Food Journal, Vol. 121 No. 9, pp. 1982-1997. https://doi.org.ezproxy.ugm.ac.id/10.1108/BFJ-10-2018-0659

45. Walinaulik. (2016). Penentuan Faktor -Faktor Pengembangan Wilayah Agropolitan Kabupaten Merauke Berbasis Komoditas Padi. ITS Repository.

46. Warseno. (, 2014). "Model Pengawasan Kawasan Teknopolitan." Journal of Industrial Engineering E Management Systems Vol. 7, No 1, February 2014.

47. Widiati, W., Mulyadi, A., Syahza, A., \& Mubarak. (, 2020). Analysis of plantation management achievement based on sustainable development. International Journal of Sustainable Development and Planning, 15(4), 575-584. DOI:10.18280/ijsdp.150418 
16 of 16

48. Yan, Y., Wang, C., Quan, Y., Wu, G., \& Zhao, J. (2018). Urban sustainable development efficiency towards the balance between nature and human well-being: Connotation, measurement, and assessment. Journal of Cleaner Production, 178(2018), 67-75. 